\title{
Makna Mendidik pada Kriya Songket Silungkang Sumatera Barat
}

\author{
Budiwirman \\ Jurusan Seni Rupa UNP Padang \\ E-mail: budi.wirman@yahoo.com
}

\begin{abstract}
One of the handicraft products related to Silungkang ceremony in West Sumatra is woven songket. This study is aimed at documenting the indigenous culture of Minangkabau which is closely linked to the existence of weaving/songket Silungkang, and reviewing the various motives of songket in the same way as the language which is used as a tool of communication. This type of research is closely linked with the methods of ethnography, then it is processed through a qualitative description. The result of the research shows that songket attire is a symbol of the livelihood of indigenous people in the value of educating people and is used for all forms of ceremonial pomp (ceremonial). Therefore, the motives of songket have a strong position as a means of communication, for a variety of motives with their meanings are part of the indigenous institutions that must be obeyed.
\end{abstract}

Keywords: Symbol, Songket, Culture

\begin{abstract}
ABSTRAK
Salah satu produk kerajinan yang terkait dengan upacara Silungkang di Sumatera Barat adalah tenunan songket. Penelitian ini bertujuan untuk mendokumentasikan budaya asli Minangkabau yang terkait erat dengan keberadaan tenun/songket Silungkang, dan mengkaji berbagai motif songket dengan cara yang sama sebagaimana bahasa yang digunakan sebagai alat komunikasi. Jenis penelitian ini berhubungan erat dengan metode etnografi, maka penelitiannya diproses melalui deskriptif kualitatif. Hasil penelitian menunjukkan bahwa pakaian songket merupakan simbol dari kehidupan masyarakat adat dalam hal mendidik masyarakat dan digunakan untuk semua bentuk kemegahan upacara (seremonial). Oleh karena itu, motif songket memiliki posisi yang sangat kuat sebagai sarana komunikasi karena berbagai motif dengan maknanya masing-masing merupakan bagian dari adat istiadat yang harus dipatuhi.
\end{abstract}

Kata kunci: simbol, songket, budaya 


\section{PENDAHULUAN}

Dalam kehidupan masyarakat Minangkabau terdapat berbagai jenis kriya yang muncul sebagai tuntutan budaya masyarakat tradisi seperti: kriya ukir, tenun/songket, sulam, tembikar/ keramik, kriya anyam dan lain sebagainya. Bentuk kriya ini pada mulanya sederhana namun pada akhirnya disempurnakan sesuai kebutuhan nagari-nagari yang ada di alam budaya Minangkabau. Di antara benda kriya yang dimaksud ada yang dipakai untuk kebutuhan fungsional, dalam pengertian dipakai untuk kebutuhan sehari-hari dan ada pula yang dipakai untuk memenuhi tuntutan upacara adat tradisi Minangkabau.

Salah satu produk kriya yang terkait dengan upacara adat yang dimaksud adalah kain tenun songket. Kain tenun ini umumnya dipakai pada setiap perayaan dan upacara adat masyarakat tradisi Minangkabau seperti upacara adat perkawinan, upacara adat pengangkatan Pangulu, Upacara adat turun mandi, dan upacara lainnya.

Ibrahim (1986) menjelaskan bahwa pakaian adat tradisional memiliki peranan penting dalam upacara-upacara adat tertentu. Melalui pakaian adat tersebut tergambar pesan-pesan, nilai-nilai budaya yang terkandung di dalamnya, serta berkaitan pula dengan aspek-aspek lain dari kebudayaan seperti ekonomi, sosial, pendidikan, politik dan keagamaan. Berkenaan dengan pesan nilai-nilai budaya yang ingin disampaikan, maka ungkapan makna itu dapat dilihat melalui berbagai sistem penandaan dari ragam cara berpakaian dan ragam hias pakaian adat tradisional tersebut.

Pembacaan makna (semantik) melalui kumpulan elemen dilakukan berdasarkan aturan-aturan tertentu misalnya (1) kapan suatu jenis pakaian adat dipergunakan, (2) siapa yang harus memakainya, dan (3) bagaimana cara memakainya. Hal ini mengikuti aturan-aturan yang telah disepakati sesuai dengan ketetapan adat di suatu nagari. Hal ini diperkuat oleh Kartiwa (1994) yang menjelaskan bahwa, kain tenun songket merupakan bagian perwujudan budaya masyarakat pemakainya. Tidak semua orang dibenarkan memakai busana ini, 
adanya nilai kesakralan, adanya persyaratan pemakainya, dan nilai simbolis sebagai pakaian kebesaran. Minarsih (1998), juga menjelaskan bahwa yang diperbolehkan memakai kain songket di dalam budaya Minangkabau adalah orang-orang tertentu (terpandang dalam masyarakatnya), yaitu pendukung upacara adat seperti (1) Bundo Kanduang, (2) Datuk dalam berbagai upacara adat dan (3) Penganten dalam upacara adat perkawinan . Betapapun kayanya seseorang dan mampu memiliki benda itu, namun ia tetap tidak diperkenankan memakai sesuka hati.

Jika pembacaan makna dapat melalui sistem kumpulan elemen (sintaktik) maka pembacaan makna visual (semantik) yang kedua adalah melalui unsur atau elemen yang terdapat pada pakaian adat (kumpulan elemen), yaitu motif hias. Budiwirman (1986), menjelaskan bahwa setiap motif hias yang terdapat pada kain tenun songket tradisional dapat mempunyai makna tertentu yang telah disepakati bersama (konvensi).

Makna sintaktik dengan metamorfosisnya atau makna elemen dapat dibaca melalui dua cara, yaitu melalui bahasa visual dan melalui bahasa verbal (misalnya melalui nama setiap motif hias). Bahasa visual mudah mengalami transformasi bentuk (ber-metamorfosis), demikian juga sintaktiknya (perubahaan susunan elemen) yang menyebabkan maknanya juga berubah (semantik). Dalam posisi ini maka pembacaan makna akan lebih mudah melalui bahasa verbal. Kedua bahasa, verbal maupun visual, memang memiliki hubungan satu dengan yang lainnya yang dibaca melalui ikon (yang menyerupai sesuatu), indeks (yang mengindikasikan sesuatu) dan simbol (kesepakatan makna, atau konvensi). Pembahasan selanjutnya ditekankan kepada pembacaan makna melalui simbol (lambang) agar dapat dipertahankan dari satu generasi ke generasi berikutnya.

Lambang, menurut Daryusti (2006), merupakan unsur yang sangat esensial dalam kehidupan manusia. Bahkan manusia disebut sebagai homosimbolicum, yang artinya sebagai pencipta dan pemberi makna melalui lambang. Lambang adalah 
"arti sesuatu” berdasarkan persetujuan bersama (konvensi), sebagai sesuatu yang memberikan sifat alamiah dan kualitas yang sama dan dapat mewakili, mengingatkan kembali, atau membayangkan dalam kenyataan atau pikiran.

Jika hal ini dikaitkan dengan perlambangan yang ada pada kain dan cara berpakaian adat Minang, maka semua gerak langkah, tindakan, dan perbuatan harus disesuaikan dengan makna yang disetujui pada pakaian adat itu. Memakai Destar berarti simbol manusia yang telah mencapai taraf pikiran yang tinggi, berpendidikan, arif dan bijaksana sesuai dengan tempatnya di kepala. Berbagai ragam hias yang terdapat pada Destar ditafsirkan maknanya oleh masyarakat tentang cara berpikir yang baik. Salah satu motif hias misalnya, Pucuk Rebung, dalam falsafah adat rebung ini adalah perlambang manusia terpakai, yang tertera dalam kata mamangan: "muda berguna, tua terpakai", menjadi contoh tauladan bagi kaumnya.

Kemudian kain tenun songket yang dijadikan pakaian seperti Baju, diistilahkan pandindiang miang, ialah suatu kain yang diperuntukkan bagi tirai yang melekat pada dinding. Makna dari kain pandindiang miang bagi masyarakat Nagari Silungkang ialah agar berjalan dan hidup penuh perasaan dengan bertitik tolak pada alam takambang dijadikan guru (alam terhampar dijadikan guru). Baju yang melekat dibadan tidak hanya dijadikan pembalut tubuh saja, melainkan diikuti oleh langan besar dan longgar. Lengan yang besar diibaratkan sebagai pengipas jika panas agar jadi sejuk baik untuk diri sendiri maupun untuk anak Kemenakan, potongan yang besar mengibaratkan sipemakai berjiwa besar, beralam lapang, bersifat sabar. Perwujudan baju ini menggambarkan sifat yang harus dimiliki serta keharusan oleh seorang pemimpin untuk ditaati ditengah kampung.

Pada dasarmya pengetahuan tentang pemakaian dan pembuatan pakaian adat beserta kelengkapannya, diajarkan secara lisan atau dengan cara menirukan dan berlangsung secara turun-temurun (Ibrahim, dkk. 1986). Pengetahuan itu hanya dicatat dalam ingatan dan berulangkali dipraktekkan setiap dibutuhkan 
oleh keluarga yang akan mengikuti upacara-upacara bersangkutan. Oleh karena semuanya tidak tertulis dan hanya ada dalam ingatan saja, maka mendorong penulis untuk melakukan penelitian dan pengkajian lebih mendalam terhadap “Makna Mendidik pada Kriya Songket Silungkang Sumatera Barat".

\section{PEMBAHASAN}

Kajian tentang makna mendidik pada kain Songket Silungkang dilakukan dengan menggunakan metodologi etnografi. Spradley (1997), menjelaskan bahwa metode etnografi adalah merupakan metode yang digunakan untuk meneliti masyarakat dan makna terhadap objek yang diteliti. Metode etnografi menyiratkan suatu cara kerja (pendataan, analisis, dan penyajian) yang bersifat menyeluruh atau holistik.

Adapun jenis penelitian yang digunakan terkait dengan metode etnografi adalah penelitian kualitatif. Penelitian ini menghasilkan temuan-temuan di lapangan yang kemudian disusun secara deskripsi kualitatif. Dengan kata lain prosedur penelitian yang menghasilkan data deskriptif berupa kata-kata tertulis atau lisan dari orang-orang dan perilaku yang dapat diamati (Bogdan,1975).

Objek penelitian ini adalah kain tenun songket sebagai ciptaan manusia. Melalui penelitian ini menunjukkan bahwa kain tenun songket mengandung unsur-unsur nilai, norma dan lambang yang sulit dipertemukan dengan faktor angka, statistik dan kuantum lainnya. Nilai, norma dan lambang hanya mungkin dipertemukan dengan gejala-gejala alami (fenomenologis), interaksi simbolik dan budaya (Moleong, 1989).

Interaksi simbolik dapat dilihat pada aspek budaya fisiknya. Diantara wujud budaya fisik yang paling menonjol interaksi simboliknya disamping bahasa visual, juga terdapat dalam bahasa verbal yaitu "petatah-petitih". Petatah-petitih mengandung lambang diskursif. Pakaian adalah bahasa visual yang mengandung lambang presentasional. Artinya petatah-petitih sebagai suatu ungkapan pikiran 
disampaikan secara berkias sekaligus merupakan lambang diskursif mengandung makna untuk dimengerti. Pakaian adat sebagai wujud budaya fisik (tangible culture) mengandung pesan untuk dipakai dan diresapi. Berarti dapat dimengerti makna-makna yang ada di dalamnya.

Dengan penggunaan metode ini, maka dapat ditemukan data yang bersifat proses kerja, deskripsi yang luas dan mendalam, perasaan, norma, keyakinan, sikap mental, etos kerja, dan budaya yang dianut seseorang maupun sekelompoknya. Dengan demikian maka akan dapat diperoleh data yang lebih luas, pasti, sehingga memiliki validitas yang tinggi dan mendalam.

Berikut ini diuraikan beberapa motif hias yang terdapat pada pakaian adat (kain songket) Silungkang, antara lain adalah:

\section{Motif Pucuak Rabuang (Pucuk Rebung)}

Motif hias pucuk rebung merupakan tafsiran nilai guna yang banyak. Pengrajin mematrikan motif ini kedalam ukiran dan kain tenunan sehingga makna dari nilai yang serba guna ini menjadi suri tauladan bagi masyarakat adat tersebut. Sama halnya Dt. Garang (1983) mengatakan, Motif ini tidak saja dipahatkan menjadi motif ukiran rumah adat, melainkan juga menjadi bentuk dasar gonjong rumah adat, hal ini dapat di lihat pada falsafah adat yakni; ketek paguno, gadang tapakai (kecil dapat digunakan, besar terpakai oleh masyarakat). Rebung ini adalah anak bambu yang keluar dari umbinya. Bentuknya seperti tumpal (kerucut) dan bersisik, kecil enak dimakan, jika rebung ini sudah besar dinamakan bambu. Perlambangan dari bambu ini adalah: Muda berguna, tua terpakai menjadi contoh bagi kaumnya.

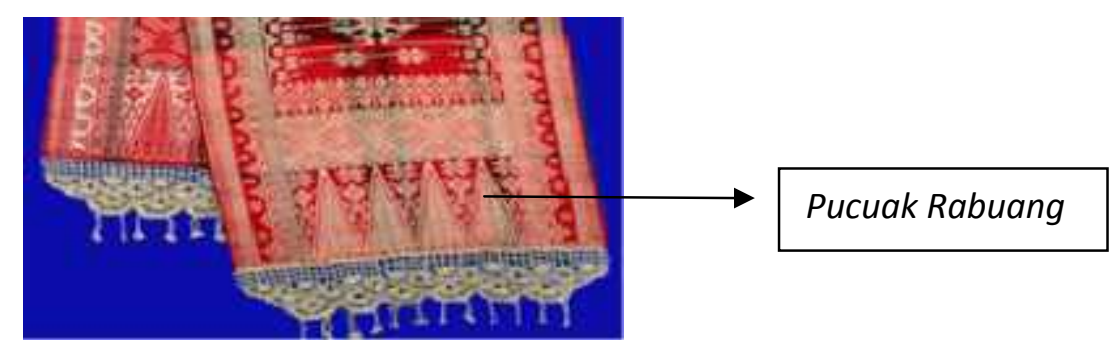


Fenomena lain yang dapat dipelajari dari bambu ini sebagaimana di jelaskan Wimar dalam Bart (2006), bahwa ketika sudah menjadi batang yang tinggi pucuknya selalu merunduk kebawah. Ini lambang dari kekuatan tanpa kesombongan, salah satu sifat yang harus dimiliki oleh seorang pemimpin. Dapat ditafsirkan bahwa, nilai mendidik yang tersirat dari motif Pucuak Rabuang, yakni pemimpin yang kuat dan punya ilmu pengetahuan serta berkharisma tinggi tentu disegani oleh banyak orang. Sementara itu rebung sebagai nilai simbolik kepemimpinan tentu belum mampu menjadi pemimpin, namun ia dapat menjadi bagian dari proses regenerasi kepemimpinan.

\section{Bada Mudiak (Ikan Teri Hidup Dihulu Sungai)}

Dalam paparan selanjutnya dapat dikatakan, bahwa "Bada Mudiak" sejenis ikan teri yang banyak hidup di laut bahagian pinggir pantai. Kehidupan ikan teri ini sangat banyak menarik perhatian manusia, sehingga orang Silungkang mengambil perumpamaan pada tingkah laku yang harus diperhatikan manusia. Ikan teri ini hidup berkelompok dan seia sekata. Hal ini dapat dilihat dari kata adat sebagai berikut; ibarat "Bada mudiak ka hulu sarombongan" (ikan teri serombongan kehulu), "Buruang Punai tabang sakawan" (bagai burung punai terbang sekawan). Perumpamaan ini menggambarkan kehidupan yang rukun dan damai seia sekata.

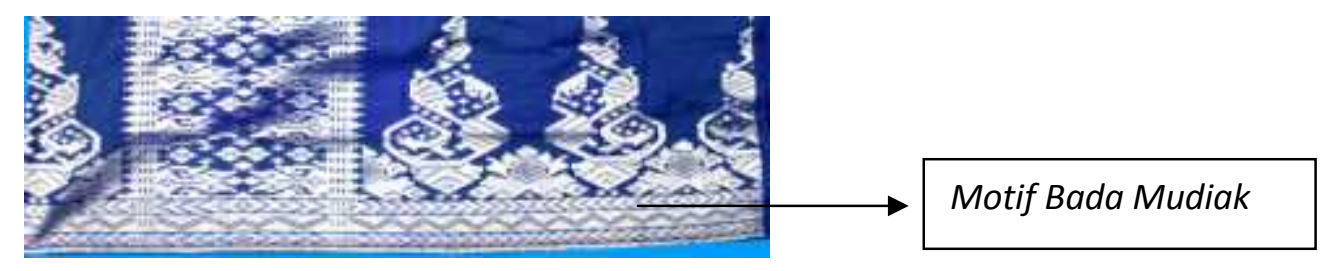

Gambar 2. Kain Tenun Songket "Sisampiang" Foto: Budiwirman 2010 
Namun mengapa ikan-ikan teri itu harus berjuang mencapai hulu sungai? Sebab, air yang jernih ada di hulu. Inilah nilai-nilai mendidik yang tersirat dari filosofi bada mudiak, yaitu untuk mendapatkan sumber yang jernih kita harus kembali kepangkal. Untuk menyelesaikan permasalahan kita harus kembali kepangkal persoalannya. Ada makna Illahi yang tersembunyi dari makna ini, bahwa untuk mencapai kebenaran haruslah kembali pada sumber yang sebenarnya, yakni kebenaran Tuhan.

\section{Saluak Laka (Alas Periuk Terbuat dari Lidi)}

Adalah jalinan yang saling membantu dan laka adalah alas periuk. Laka terbuat dari lidi kelapa. Jalinan lidi itu dibentuk bulat dan dapat menampung periuk. Jadi bentuk dasarnya seperti bagian bawah periuk. Ragam hias ini memaknai sistim keakraban kehidupan masyarakat yang jalinan kekerabatannya sangat erat dalam menggalang kekuatan untuk mendukung tanggung jawab yang sangat berat sekalipun. Ada petatahpetitih adat yang menyatakan;

(Yang berkait seperti laka Yang berkait seperti gagang Agar tali tidak putus

Nan basaluak bak laka

Kait berkait tidak terberai).

Nan bakaik bak gagang

Supayo tali nak jan putuih

Kaik bakaik nak jan ungkai

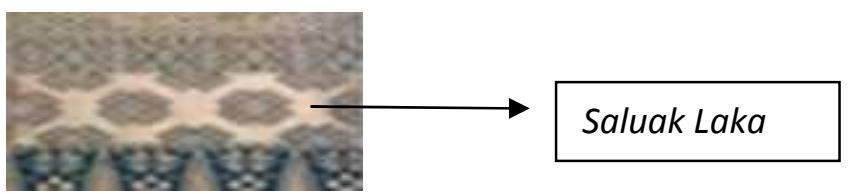

Gambar 3. Kain Tenun Songket "Salempang"

Foto: Budiwirman 2010

Anyaman laka sangatlah rapi, tidak terlihat pangkal lidi atau ujung lidi menjulur keluar, semua tersembunyi ke bagian bawah. Inilah simbol dari masyarakat yang bersatu akan memunculkan banyak kekuatan, tetapi tetap rendah hati. Kekuatan tersebut dibangun atas dasar kerja sama dan keikhlasan. Individu-individu bersatu dan lebur sebagai sebuah kekuatan 
bersama. Tidak ada yang menonjolkan keilmuannya atau merasa lebih berjasa dari yang lainnya.

\section{Buah Palo Bapatah (Buah Pala yang Dipatahkan)}

Pala (Palo bhs. Minang) dikenal sebagai bahan rempah-rempah yang banyak manfaatnya, baik untuk bumbu penyedap masakan maupun sebagai bahan dasar untuk obat-obatan. Jika buah pala dipatahkan (dibelah) menjadi dua, akan menampakkan isi yang menyerupai ragam hias yang bagus dan indah.

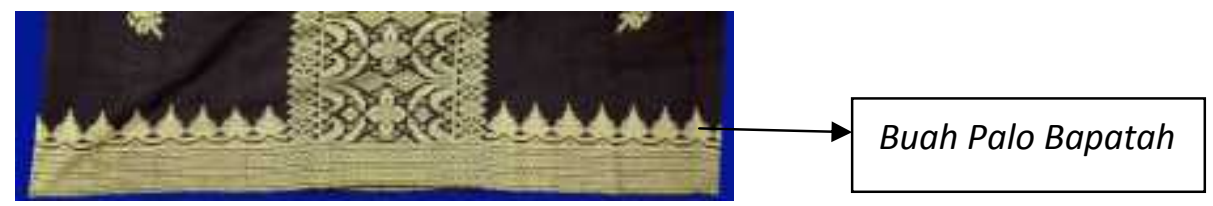

Gambar 4. Kain Tenun Songket "Sisampiang"

Foto: Budiwirman 2010

Manfaat buah pala dibelah dua menyiratkan nilai simboliknya untuk mendidik yaitu, adanya keinginan untuk saling berbagi menikmati keindahan, saling berbagi rasa senang. Keindahan dan rasa senang tidak dibatasi menjadi milik sekelompok kecil orang dan tidak dibiarkan tersimpan di dalam lingkaran tertutup. Sebab dalam lingkaran tertutup bukanlah keindahan, dan tidak bisa dinikmati keindahannya secara sempurna.

\section{Sirangkak (Kepiting)}

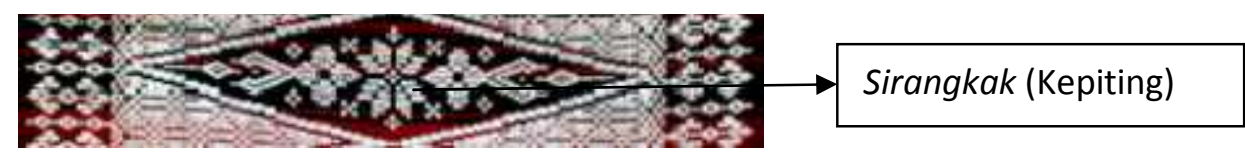

Gambar 5. Kain Tenun Songket "Sandang"

Foto: Budiwirman 2010

Sirangkak adalah semacam kepiting yang suka hidup dalam air atau setengah kering. Ia suka merangkak, menggapai sambil menjepit kian kemari. Sifat jepitannya ini akan menjadi bermakna bila jika manusia adalah 
sangat menyakitkan, apalagi yang disakiti itu manusia yang tiada berdaya, dan ini biasanya digunakan untuk sindiran.

\section{Barantai (saling mengikat).}

Motif barantai disebut, barantai merah dan barantai putih. Ini melambangkan persatuan yang tidak boleh putus-putus antara dua makhluk Tuhan Laki-laki dan wanita.

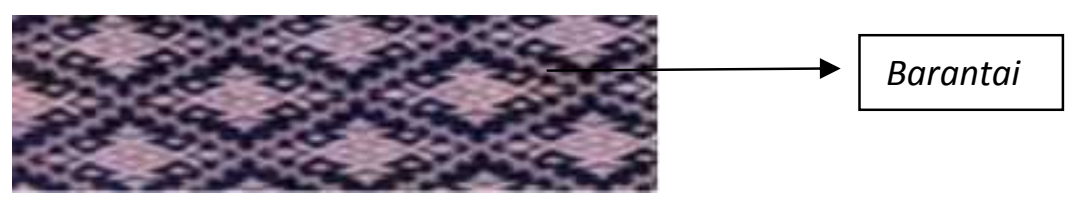

Gambar 6. Kain Tenun Songket "Sisampiang"

Foto: Budiwirman 2010

\section{Tirai Pucuak Jaguang (Serabut yang Terdapat pada Ujung Jagung)}

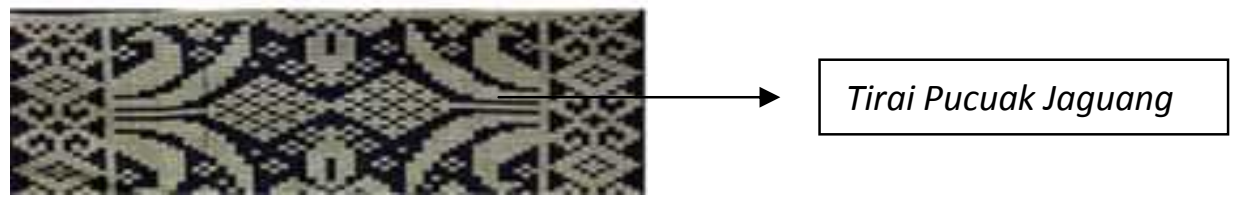

Gambar 7. Kain Tenun Songket "Sisampiang"

Foto: Budiwirman 2010

Jika buah jagung mulai mekar, maka pada ujung jagung tumbuhlah serabut-serabut yang halus dan banyak. Serabut ini adakalanya menjulai kebawah. Bentuk-bentuk ini memberi inspirasi kepada penenun untuk diterapkan pada motif tenun yang simbolisnya adalah; padi masak jagung maupiah atau padi masak jagung berbuah banyak. Jadi tentang jagung ini dapat pula di jadikan sebagai nilai simboliknya salah satu lambang kemakmuran.

\section{Balah Kacang (Belahan Kacang)}

Sebagai sindiran lah lupo kacang jo kuliknyo (sudah lupa kacang pada kulitnya), artinya kacang yang dibelah akan menampakkan isinya, isi ini merupakan cikal bakal yang akan tumbuh menjadi tunas baru. Ungkapan ini mengandung arti nilai simboliknya pada pengajaran, bahwa sewaktu 
membuka diri hendaklah memperlihatkan niat yang baik tanpa menyombongkan diri dengan menunjukkan kemampuan ataupun kekayaan yang dimiliki.

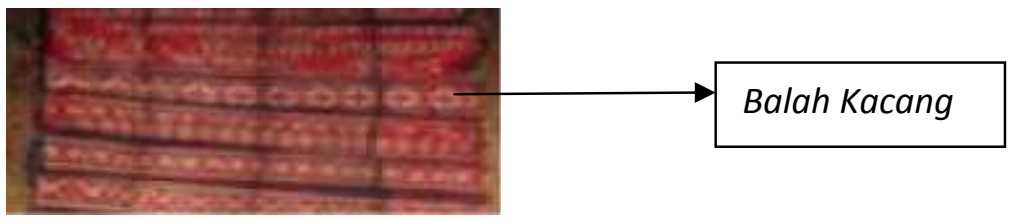

Gambar 8. Kain Tenun Songket "Sisampiang"

Foto: Budiwirman 2010

\section{Saik Ajik dan Saik Kalamai (Sejenis Dodol)}

Saik Ajik adalah makanan tradisional yang terbuat dari tepung ketan dan gula merah, berwarna coklat tua, dan sangat manis. Saik Kalamai berarti sayatan gelamai yang berpotongan jajaran genjang. Kalamai selalu disajikan berupa sayatan-sayatan kecil, dan tidak pernah dihidangkan dalam bentuk sayatan besar, ini di simbolkan agar makanan tersebut dikosumsi secara sedikit demi sedikit. Saik Kalamai ini mengandung arti nilai simboliknya pada kehidupan yang hemat dan terencana.

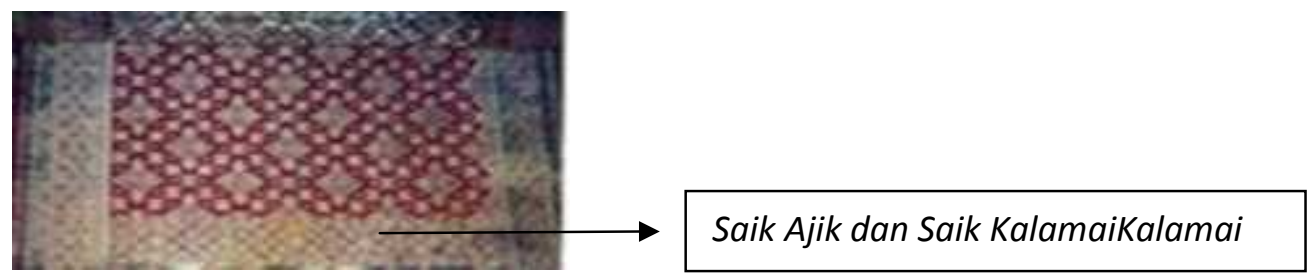

Gambar 9. Kain Tenun Songket "Sisampiang"

Foto: Budiwirman 2010

Tabel Motif Hias dan Maknanya:

\begin{tabular}{|c|c|c|c|c|}
\hline \multirow{2}{*}{ NO } & \multirow{2}{*}{ MOTIF HIAS } & \multicolumn{3}{|c|}{ MAKNA } \\
\hline & & NILAI & NORMA & LAMBANG \\
\hline 1. & $\begin{array}{l}\text { Pucuak Rabuang } \\
\text { (Pucuk } \\
\text { Rebung/Anak } \\
\text { Bambu) }\end{array}$ & $\begin{array}{l}\text { Muda berguna tua } \\
\text { terpakai }\end{array}$ & $\begin{array}{l}\text { Sebagai panutan } \\
\text { kaumnya }\end{array}$ & $\begin{array}{l}\text { Melambangkan } \\
\text { kekuatan tanpa } \\
\text { kesombongan/suri } \\
\text { tauladan. }\end{array}$ \\
\hline 2. & $\begin{array}{l}\text { Bada Mudiak (Ikan } \\
\text { Teri Hidup di hulu }\end{array}$ & $\begin{array}{l}\text { Tingkah laku/ } \\
\text { perilaku sehari-hari }\end{array}$ & $\begin{array}{l}\text { Sebagai panutan } \\
\text { kaumnya }\end{array}$ & $\begin{array}{l}\text { Kehidupan yang } \\
\text { rukun dan damai }\end{array}$ \\
\hline
\end{tabular}


sungai)

3. Saluak Laka (Alas

Periuk terbuat dari

Lidi daun kelapa).

4. Buah Palo Bapatah (buah Pala yang dipatahkan).

5. Sirangkak

(Kepiting)

6. Barantai (saling tersambung).

7. Tirai Pucuk Jagung (Serabut yang terdapat pada ujung jagung)

8. Balah Kacang (kacang dibelah dua)

9. Saik Ajik dan Saik Kalamai (Potongan sejenis dodol).
Bersatu untuk membangun

kekuatan

Tidak Menutup diri/ hidup selalu berbagi

Menyakitkan

Makhluk Tuhan

yang saling berhubungan

Masyarakat yang sejahtera.

Pengajaran terhadap

Masyarakat

Hemat/tidak boros

Sebagai panutan kaumnya

Sebagai panutan

Sebagai panutan

kaumnya

Sebagai panutan

kaumnya

Sebagai panutan kaumnya

Sebagai panutan kaumnya
Keakraban Hidup bermasyarakat

Membagi rasa senang/kebahagiaan

Sindiran

Persatuan

Kemakmuran dalam masyarakat

Membuka diri/ terbuka terhadap masyarakatnya

Hemat dan terencana

Tabel di atas menggambarkan tentang simbolik pendidikan yang terkandung dalam motif hias songket Silungkang, pada prinsipnya motifmotif hias itu ditata sedemikian rupa yang dapat mencerminkan kepribadian sipemakainya dan serasi betul dengan apa yang disebut etika, atau tata krama yang berlaku di Nagari Silungkang.

\section{PENUTUP}

Didasari analisa yang dilakukan, sebagai akhir dari rangkaian penelitian, maka dapat disimpulkan bahwa motif hias yang terdapat pada kain tenun songket 
sebagai pakaian adat di Silungkang Sumatera Barat prinsipnya merupakan bagian yang tak dapat dipisahkan dari eksistensi seorang pemangku adat di kultur kaumnya. Motif-motif yang tertera pada kain tenun songket itu kiranya lebih dari pada sekedar hiasan belaka, namun ia dapat diterjemahkan, sekaligus merupakan simbol atau lambang yang bermakna mendidik, dia dapat menjadi tauladan dalam peri kehidupan sehari-hari dalam masyarakat adat di Minangkabau, dan khususnya di Nagari Silungkang.

\section{DAFTAR PUSTAKA}

AM. Yosef Dt. Garang, dkk.

1983 Pengetahuan Ragam Hias Minangkabau. Padang: Proyek Pengadaan Buku Pendidikan Menengah Kejuruan, Dep. P dan K. Sumbar.

Bart, Bernhard.

2006 Revitalisasi Songket Lama Minangkabau. Padang: Studio Songket Erikarianti.

Bogdan, Robert and Steven J. Taylor.

1975 Introduction to Qualitative Research Methods (The Search For Meaning).

New York: John Wiley \& Son.

Budiwirman.

1986

Studi tentang Kain Tenun Songket Tradisional Balapak

Minangkabau. Skripsi/S.1, Yogyakarta: ISI

Daryusti.

2006

Hegemoni Pangulu dalam Perspektif Budaya,Jakarta: Penerbit Pustaka.

Ibrahim, Anwar,dkk.

1986 Pakaian Adat Tradisional daerah Sumatera Barat. Padang: Departemen

Pendidikan dan Kebudayaan, Direktorat Jenderal Kebudayaan,

Direktorat Sejarah dan Nilai Tradisional, Proyek Inventarisasi

Dokumen Daerah.

Minarsih. 

Sumatera Barat. Tesis. Bandung: ITB.

Moleong, Lexy J.

1989 Metodologi Penelitian Kualitatif, Bandung: Penerbit Remaja Karya CV.

Spradley P.James.

1997 Metode Etnografi. Yogyakarta: PT.Tiara Wacana 